\title{
Determination of Macro- and Microelements in the Inflorescences of Banana Tree Using ICP OES: Evaluation of the Daily Recommendations of Intake for Humans
}

\author{
Rafaela Henriques Rosa $\left(\mathbb{D},{ }^{1}\right.$ Melina Ribeiro Fernandes $\left(\mathbb{D},{ }^{1}\right.$ Elaine Silva de Pádua Melo $(\mathbb{D}),{ }^{1}$ \\ Daniela Granja Arakaki $\left(\mathbb{D},{ }^{1}\right.$ Nayara Vieira de Lima ${ }^{D},{ }^{1}$ Luana Carolina Santos Leite, \\ Paulo Renato Espindola $\left(\mathbb{D},{ }^{2}\right.$ Igor Domingos de Souza $\mathbb{D}^{\mathbb{D}},{ }^{1}$ Valdir Aragão do Nascimento $\left(\mathbb{D},{ }^{1}\right.$ \\ Paula Fabiana Saldanha Tschinkel $\left(\mathbb{D},{ }^{1}\right.$ Fabiane La Flor Ziegler Sanches $\mathbb{D}^{3}{ }^{3}$ \\ and Valter Aragão do Nascimento (iD ${ }^{1}$
}

${ }^{1}$ Group of Spectroscopy and Bioinformatics Applied Biodiversity and Health (GEBABS), Graduate Program on Health and Development in West Central Region, School of Medicine, Federal University of Mato Grosso do Sul, UFMS, 79070-900 Campo Grande, Brazil

${ }^{2}$ Institute of Physics of the Federal University of Mato Grosso do Sul, Campo Grande, Mato Grosso do Sul, Brazil

${ }^{3}$ Faculty of Pharmaceutical Sciences, Food and Nutrition, Federal University of Mato Grosso do Sul, 79070-900 Campo Grande, Brazil

Correspondence should be addressed to Valter Aragão do Nascimento; aragao60@hotmail.com

Received 20 March 2020; Revised 2 October 2020; Accepted 13 October 2020; Published 17 November 2020

Academic Editor: Nirmal Kumar Sarkar

Copyright ( $\odot 2020$ Rafaela Henriques Rosa et al. This is an open access article distributed under the Creative Commons Attribution License, which permits unrestricted use, distribution, and reproduction in any medium, provided the original work is properly cited.

\begin{abstract}
The inflorescence of Musa paradisiaca, known as "banana heart" is a structure that includes flowers and bracts of banana, commonly used as food source worldwide. The aims of this study were (1) to determine the mineral components of Musa paradisiaca and (2) to compare the obtained results with previously reported data of Recommendation Dietary Allowances (RDAs) and edible plant permissible limits set by FAO/WHO. The samples were digested using microwave-assisted equipment, while elemental contents were determined by inductively coupled plasma optical emission spectroscopy (ICP OES). Metal (Mg, $\mathrm{Ca}, \mathrm{Cr}, \mathrm{Ni}, \mathrm{Cu}, \mathrm{Fe}$, and $\mathrm{Zn}$ ) and nonmetal ( $\mathrm{S}$ and $\mathrm{P}$ ) contents were detected. According to $\mathrm{RDA}$, the inflorescences could be excellent sources of $\mathrm{Mg}, \mathrm{P}, \mathrm{Cr}, \mathrm{Cu}, \mathrm{Zn}$, and Fe for females, males, and pregnant women, all age 31-50 y, as well as children (4-8 y). Bracts are good source of $\mathrm{Zn}$ for male and pregnant women and good source of Fe for children. All the samples contained considerable amounts of $\mathrm{Mg}, \mathrm{Ca}, \mathrm{P}, \mathrm{Ni}, \mathrm{Cu}, \mathrm{Zn}$, and $\mathrm{Fe}$, which were quite low to induce deleterious effects (UL). FAO/WHO limits for edible plants have not yet been established for $\mathrm{S}, \mathrm{P}, \mathrm{Mg}$, and $\mathrm{Ca}$, but $\mathrm{Ni}$ and $\mathrm{Zn}$ are below of those limit values. However, Cr and $\mathrm{Cu}$ concentrations are higher than the values established for edible plants and may pose a threat to human health. Farmers should be encouraged by government agencies, not only for sustainability of production but also to ensure the storage and trade of banana tree inflorescence.
\end{abstract}

\section{Introduction}

A banana is an edible fruit produced by the banana tree. There are considerable differences concerning cultural practices and utilizations of the banana fruit and its peel by populations [1]. The fruits grow in clusters hanging from the top of the plant. Musa paradisiaca (plantain) is the accepted name for the hybrid between Musa acuminata and Musa balbisiana [2]. M. paradisiaca is a herbaceous plant of the genus Musa being sourced from tropical and subtropical countries such as Sri Lanka and eastern India and regions of other countries as China and Australia [3]. There is a great diversity of cultivated bananas. Thus, many other names are synonyms of M. paradisiaca, such as M. corniculata Lour [3]. 
The fruit of $M$. paradisiaca is a good source of potassium, calcium, and phosphorus and is also a rich source of iron and vitamins $\mathrm{C}$ and $\mathrm{E}[4,5]$. M. paradisiaca has potential health benefits [6] as well as cancer chemoprevention activities [7]. Several parts of the banana tree serve as raw material for making ropes or are used in religious ceremonies and clothing manufacturing [8]. According to the Food and Agriculture Organization of the United Nations (FAO) estimates, India produced 29 million tons of banana per year on average between 2010 and 2017. China follows it with 11 million tons, the Philippines with an annual average of 7.5 million tons from 2010 to 2017, and Brazil an average of 7 million tons [9].

In Brazil, due to socioeconomic conditions and search for healthier nonconventional foods, banana inflorescences are used as food by the population; farmers even discard this part during the collection of fruits [10]. The inflorescence is constituted of the mating and floral axis (raque), where the flowers are inserted in pence consisting of two horizontal and parallel rows. The banana tree's inflorescence is popularly known as the "banana heart" or "navels," which is used to make salads or used in the form of dry flour as food in several Brazil regions. The inflorescences of the banana tree (male flowers and bracts) are commonly used as vegetables for cooking in Laos, Thailand, China, Burma, Philippines, Sri Lanka, Vietnam, and India cooking methods vegetables were adopted [11].

Due to the indiscriminate use of fertilizers and pesticides for crop protection and pest control, fruits [12] and the banana tree are being contaminated by heavy metals [13]. High levels of $\mathrm{Na}, \mathrm{Pb}, \mathrm{Cr}, \mathrm{Fe}, \mathrm{Mn}, \mathrm{Cd}, \mathrm{Zn}$, and $\mathrm{Se}$ in the banana may have been attributed to the repeated use and addition of residues as fertilizers in agricultural areas of banana [14]. Besides, studies on banana plants that are grown in industrial areas have elevated levels of $\mathrm{Cd}, \mathrm{Co}, \mathrm{Cu}$, $\mathrm{Fe}, \mathrm{Pb}, \mathrm{Ni}$, and $\mathrm{Zn}[15]$. According to Romero-Estévez et al. [16], there is no significant health risk to the consumer associated with banana fruits with contamination levels of $\mathrm{Cd}$ and $\mathrm{Ni}$, but there is $\mathrm{Pb}$ risk for toddlers. In fact, the heavy metal concentration in fruits, legumes, vegetables, and animals is influenced by the environmental factors (agriculture fertilizers, pollution, climate, and physicochemical properties and soil type) where they are growing [17-20]. Toxic elements $(\mathrm{Cd}, \mathrm{Pb}, \mathrm{Cu}$, and $\mathrm{Zn})$ are present in herbs [21], animals, and other types of food according to proven studies in several countries [22-24]. Therefore, it is essential to monitor food quality once plants accumulate heavy metals [25]. Macro- (Ca, P, Na, S, K, and Mg) and microelements (B, Cl, Cr, Cu, F, I, Fe, Li, Co, Mn, Mo, Ni, Se, Na, V, and Zn) play decisive roles in the human metabolism and are necessary for good health [26, 27]. However, large amounts of these nutrients through oral ingestion can cause health risks to farmers and consumers.

Each element's potential contribution to healthy people was stipulated by dietary reference intakes (DRIs) [28]. DRIs encompass four types of nutrient reference values, including the RDA, which is an average daily dietary intake level; the Adequate Intake (AI) being a value based on experimentally derived intake levels or approximations of observed mean nutrient intakes by a group (or groups) of healthy people; the Tolerable Upper Intake Level (UL), meaning the highest level of a daily nutrient that is likely to pose no risk or adverse effects to almost all individuals in the general population; and the Estimated Average Requirement (EAR) is the intake level for a nutrient at which the need of 50 percent of the people will be met).

The quantification of metals and nonmetals in human foods can be performed using analytical methods. Thus, the value of quantification in samples by ICP OES can be used to stipulate the potential contribution of each element to healthy individuals established by the DRIs [29-32]. In fact, from spectroscopic techniques and stipulated values of daily intake (RDA/AI and UL), it is possible to perform calculations that estimate the necessary intake of each element required to maintain human health or may cause toxicity $[33,34]$. In some countries, the environmental factors in unconventional food plants are not subject to strict control. Food security can be provided by looking at the information on molecular composition, process intermediates, and quality parameters, which can be assessed by infrared spectroscopy in both liquid and gas phases [35]. In addition, molecular identification in biological sample in gas phase using infrared spectroscopy can assist in diagnosing diseases in the human body or to ensure its safety [36].

Motivated by the manuscript published by Oyeyinka and Afolayan [33], which emphasizes that the peel and its derivative extract, as well as the flesh of $M$. sinensis L. and M. paradisiaca L., are relevant to human nutritional, we believe the inflorescence and flowers of $M$. paradisiaca are also essential for health. There is no information on the concentration of metals and nonmetals in the inflorescence of other banana species such as M. paradisiaca L., which is consumed by the indigenous, urban, and rural population of central-western Brazil and other countries [11]. This study aimed to determine and compare for the first time the contents of the metals ( $\mathrm{Mg}, \mathrm{Ca}, \mathrm{Cr}, \mathrm{Ni}, \mathrm{Cu}, \mathrm{Fe}$, and $\mathrm{Zn}$ ) and nonmetals ( $\mathrm{S}$ and $\mathrm{P}$ ) in the inflorescence of $M$. paradisiacal L. (male flowers and bracts) with the specification limits of RDA, AI, and UL values for male, female, children, and pregnancy [28]. In addition, comparisons were also made, considering the limits established for edible plant permissible limits set by FAO/WHO [37]. It is very important to know the concentration of heavy metals and nonmetals in plants and fruits to estimate their role as sources of components in the diet and workers' and producers' safety. The collection of the samples was performed several times from in the urban area of the city of Campo Grande, Brazil. The samples of the inflorescence of $M$. paradisiacal L. selected for our research underwent a microwave-assisted digestion process, after which ICP OES determined the macrocontent and microelements.

\section{Materials and Methods}

2.1. Collection and Identification of Vegetable Material. For the analysis of chemical elements, a total of 16 samples of inflorescences of banana trees ( $M$. paradisiaca L., Musaceae) were collected in May 2019 in a smallholding near the urban 
area of the city of Campo Grande, Mato Grosso do Sul, Brazil. Samples of this banana tree species have already been identified by the herbarium of the Federal University of Mato Grosso do Sul on 26/06/2016, deposit No. 53972 CGMS. Male flowers are produced within bracts near the apex of the floral stalk (Figure 1). In accordance with Brazilian law, this research was registered in the National Genetic Resource Management System and Associated Traditional Knowledge (SisGen, No. A7716EC).

2.2. Sample Preparation and Digestion. A quantity of $100 \mathrm{~g}$ of flowers (bracts) of several banana trees (about 20) was collected and mixed for analysis. The flowers and bracts were set to dry in an oven at $50^{\circ} \mathrm{C}$ for 72 hours until their weights stabilized. The dried samples of flowers and bracts were crushed separately with a portable stainless steel electric grinder to obtain a very fine powder. About $0.250 \mathrm{~g}$ of flowers (as well as $0.250 \mathrm{~g}$ bracts) were weighed on an analytical balance, transferred inside Teflon vessels (in triplicate), and $3 \mathrm{ml}$ of nitric acid $\left(\mathrm{HNO}_{3} 65 \%\right.$ Merck), $2 \mathrm{ml}$ of hydrogen peroxide $\left(35 \% \mathrm{H}_{2} \mathrm{O}_{2}\right.$, Merck), and $1 \mathrm{ml}$ of ultrapure water (conductivity $18.2 \mathrm{M} \Omega \mathrm{cm}$ produced Millipore, Water Purification System Milli-Q Biocel, Germany) were added. For the calibration blank, $1 \mathrm{ml}$ of ultrapure water and $2 \mathrm{ml}$ of nitric acid in $1 \mathrm{ml}$ of $\mathrm{H}_{2} \mathrm{O}_{2}$ was used.

Once you have all the steps mentioned above in place, the mixture was allowed to remain in the open air for 10 min predigestion and then digested using a microwave digestion equipment (BERGHOF Products + Instruments GmbH-Speedwave 4-Microwave Digestion System). All digestion processes were carried out using the operating program specified in Table 1.

2.3. Elemental Analysis by ICP OES Technique. After the microwave system's digestion procedure, the contents of the vessels were transferred to the $50 \mathrm{ml}$ Falcons vessel and then filled to $30 \mathrm{ml}$ with ultrapure water. Also, the elements were determined by the technique of ICP OES (Thermo Fisher Scientific, Bremen, Germany, iCAP 6300 Duo). The selected emission lines (wavelength in $\mathrm{nm}$ ) for determining elements in flowers, bracts, and operating conditions of ICP OES are summarized in Table 2.

2.4. Calibration Curves. For the ICP-OES method, multielement stock solutions containing $1000 \mathrm{mg} / \mathrm{L}$ of Al, As, Ca, $\mathrm{Cd}, \mathrm{Co}, \mathrm{Cr}, \mathrm{Cu}, \mathrm{Fe}, \mathrm{Mg}, \mathrm{Mn}, \mathrm{Mo}, \mathrm{Na}, \mathrm{Ni}, \mathrm{P}, \mathrm{S}, \mathrm{V}$, Se, and $\mathrm{Zn}$ were obtained from SpecSol (SpecSol, Quimlab, Brazil), and analytical calibration standards were prepared. For each element detected (Table 3), a limit of quantification (LOQ), limit of detection (LOD), and correlation coefficient $\left(R^{2}\right)$ were established according to [38]. A blank and a sevenpoint calibration curve were generated using the following concentrations: $0.01,0.02,0.05,0.2,1.0,2.0$, and $5.0 \mathrm{mg} / \mathrm{L}$ of the all element standard. Triplicate analyses were performed for each sample.

The accuracy was also verified by addition and recovery, where it was found that our quantification analyses for each
Inflorescences of the $M$. paradisiaca $\mathrm{L}$.

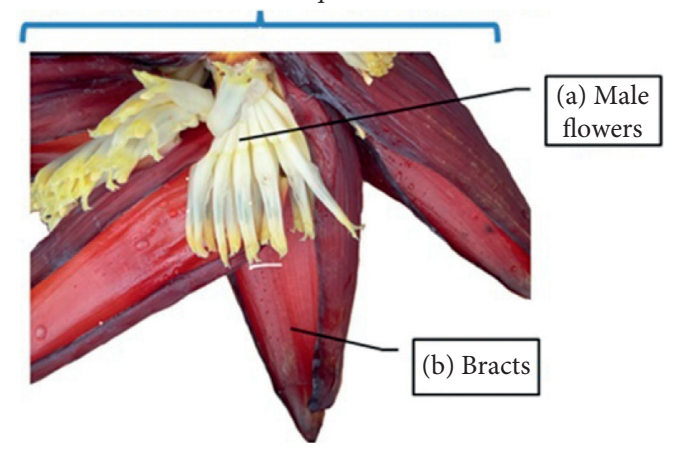

Figure 1: Inflorescence of M. paradisiaca L. (a) Male flowers and (b) bracts.

element were detected with good precision (i.e., standard deviation (SD) between 0.01 and 0.3 ), as explained in Table 4 .

2.5. Statistical Analysis. The statistical package for social sciences (SPSS), version 18.0 (SPSS Inc. Chicago, IL, USA), was used to study the differences in contents between flowers and bracts of the banana tree's inflorescence. Results are presented as mean \pm standard deviation. The KolmogorovSmirnov test was used to verify the normality of the data of the contents of flowers and bracts obtained by ICP OES. After checking for normality, the Student's $t$ test was used to compare the means. It was adopted $p<0.05$ as a level of significance.

\section{Results and Discussion}

Results showed that seven metal $(\mathrm{Mg}, \mathrm{Ca}, \mathrm{Cr}, \mathrm{Ni}, \mathrm{Cu}, \mathrm{Fe}$, and $\mathrm{Zn}$ ) and two nonmetal ( $\mathrm{S}$ and $\mathrm{P}$ ) contents were detected in the inflorescence of the banana tree (Table 5). Each sample was analyzed three times by the ICP OES, and the results were expressed as mean $\pm \mathrm{SD}$. The elements as sodium $(\mathrm{Na})$, selenium (Se), vanadium (V), manganese ( $\mathrm{Mn})$, molybdenum (Mo), cobalt (Co), cadmium (Cd), aluminium ( $\mathrm{Al}$ ), and arsenium (As) are below the limit of detection (LOD). According to results of Student's $t$ test (Table 5), there was a significant difference between the contents of flowers and bracts for sulfur $(\mathrm{S})$, phosphorus $(\mathrm{P})$, calcium $(\mathrm{Ca})$, copper $(\mathrm{Cu})$, and zinc $(\mathrm{Zn})(p<0.001)$. On the other hand, there was no statistically significant difference between magnesium $(\mathrm{Mg})$, chromium $(\mathrm{Cr})$, nickel $(\mathrm{Ni})$, and iron $(\mathrm{Fe})$ elements in leaves and bracts $(p>0.05)$ between flowers and bracts.

Although some elements are below the detection limit, some have an accumulative effect or lead to health problems in humans due to the low or high concentrations [39]. Table 6 list the levels of nonmetals and metals quantified $(\mathrm{mg} / 100 \mathrm{~g})$ in the inflorescence of the banana tree compared to the limit specification of RDAs, AI, and UL values of males (31-50 y) and females (31-50y), children (4-8y), and pregnant women (31-40y) [28]. Besides, all values obtained in this manuscript were compared with the permissible limits set by the FAO/WHO for edible plants [36]. 
TABLE 1: Microwave digestion parameters.

\begin{tabular}{|c|c|c|c|c|c|}
\hline Step & Power $(\mathrm{W})$ & Temperature $\left({ }^{\circ} \mathrm{C}\right)$ & Ramp time (min) & Hold time (min) & Pressure (Bar) \\
\hline 1 & 1305 & 170 & 5 & 10 & 35 \\
\hline 2 & 1305 & 200 & 1 & 15 & 35 \\
\hline 3 & 0 & 50 & 1 & 10 & 0 \\
\hline 4 & 0 & 50 & 1 & 10 & 0 \\
\hline 5 & 0 & 50 & 1 & 1 & 0 \\
\hline
\end{tabular}

TABLE 2: Instrumental analytical conditions for ICP OES of element analyses.

\begin{tabular}{|c|c|}
\hline Parameters & Setting \\
\hline RF power $(\mathrm{W})$ & 1250 \\
\hline Sample flow rate $\left(\mathrm{L} \mathrm{min}^{-1}\right)$ & 0.45 \\
\hline $\begin{array}{l}\text { Plasma gas flow rate } \\
\left(\mathrm{L} \min ^{-1}\right)\end{array}$ & 12 \\
\hline Integration time $(\mathrm{s})$ & 5 \\
\hline Stabilization time (s) & 20 \\
\hline $\begin{array}{l}\text { Pressure of nebulization } \\
(\mathrm{p} \mathrm{si})\end{array}$ & 20 \\
\hline Plasm view & Axial \\
\hline Gas $(99.999 \%)$ & $\mathrm{Ar}$ \\
\hline $\begin{array}{l}\text { Analytical wavelength } \\
(\mathrm{nm})\end{array}$ & 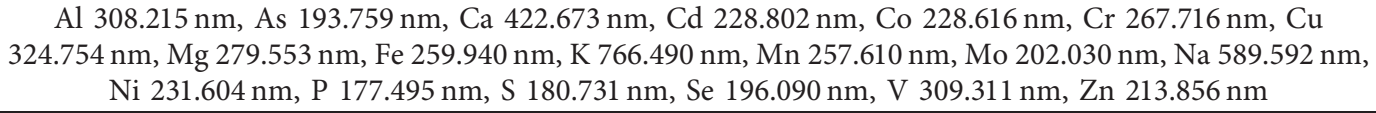 \\
\hline
\end{tabular}

TABLE 3: Parameters of calibration obtained external calibration: correlation coefficient $\left(R^{2}\right)$, LOD, and LOQ by using ICP OES.

\begin{tabular}{lccc}
\hline Elements & ${ }^{*} R^{2}$ & ${ }^{* *} \mathrm{LOD}\left(\mathrm{mgL}^{-1}\right)$ & ${ }^{* * *} \mathrm{LOQ}\left(\mathrm{mgL}^{-1}\right)$ \\
\hline $\mathrm{Al}$ & 0.9996 & 0.001 & 0.003 \\
$\mathrm{As}$ & 0.9999 & 0.001 & 0.004 \\
$\mathrm{Ca}$ & 0.9999 & 0.00009 & 0.0001 \\
$\mathrm{Cd}$ & 0.9998 & 0.00008 & 0.0003 \\
$\mathrm{Co}$ & 0.9999 & 0.002 & 0.0008 \\
$\mathrm{Cr}$ & 0.9999 & 0.002 & 0.006 \\
$\mathrm{Cu}$ & 0.9997 & 0.002 & 0.006 \\
$\mathrm{Fe}$ & 0.9999 & 0.0005 & 0.002 \\
$\mathrm{~K}$ & 0.9996 & 0.0001 & 0.0003 \\
$\mathrm{Mg}$ & 0.9999 & 0.00002 & 0.00006 \\
$\mathrm{Mn}$ & 0.9999 & 0.0001 & 0.003 \\
$\mathrm{Mo}$ & 0.9999 & 0.0003 & 0.001 \\
$\mathrm{Na}$ & 0.9997 & 0.0001 & 0.0005 \\
$\mathrm{Ni}$ & 0.9999 & 0.0005 & 0.002 \\
$\mathrm{P}$ & 0.9999 & 0.003 & 0.01 \\
$\mathrm{~S}$ & 0.9999 & 0.002 & 0.006 \\
$\mathrm{Se}$ & 0.9994 & 0.0009 & 0.003 \\
$\mathrm{~V}$ & 0.9999 & 0.0003 & 0.0009 \\
$\mathrm{Zn}$ & 0.9996 & 0.00009 & 0.003 \\
\hline${ }^{*} R^{2}$ correlation & coefficient; ${ }^{* *} \mathrm{LOD}:$ limit of detection; ${ }^{* * *} \mathrm{LOQ}:$ limit of \\
quantification. & & & \\
& & &
\end{tabular}

This manuscript adopted the Nutrition Content Claims based on FDA, which proposed that foods with $10-19 \%$ of the daily value per portion are "good source of" nutrition, while foods that contain $20 \%$ or more than daily values per portion are considered "excellent source of" nutrition [40]. As shown in Table 6, the concentration of nonmetal in the flowers and bracts decrease in the order $\mathrm{P}>\mathrm{S}$ and metal $\mathrm{Ca}>\mathrm{Mg}>\mathrm{Zn}>\mathrm{Fe}>\mathrm{Cu}>\mathrm{Ni}>\mathrm{Cr}$. The discussions on the concentration of each element obtained in the flowers and bracts in this manuscript are present[[parms resize(1),
TABle 4: Addition and recovery tests $(n=3)$.

\begin{tabular}{lccc}
\hline Analyte & Added $(\mathrm{mg} / \mathrm{L})$ & Obtained value $(\mathrm{mg} / \mathrm{L})$ & Recovery $(\%)$ \\
\hline $\mathrm{Al}$ & 1.00 & $1.00 \pm 0.05$ & 100.00 \\
$\mathrm{As}$ & 1.00 & $0.89 \pm 0.01$ & 89.00 \\
$\mathrm{Ca}$ & 1.00 & $1.07 \pm 0.06$ & 107.00 \\
$\mathrm{Cd}$ & 1.00 & $0.98 \pm 0.12$ & 98.00 \\
$\mathrm{Co}$ & 1.00 & $1.03 \pm 0.10$ & 103.00 \\
$\mathrm{Cr}$ & 1.00 & $1.06 \pm 0.30$ & 106.00 \\
$\mathrm{Cu}$ & 1.00 & $1.05 \pm 0.20$ & 105.00 \\
$\mathrm{Fe}$ & 1.00 & $0.99 \pm 0.10$ & 99.00 \\
$\mathrm{~K}$ & 1.00 & $0.94 \pm 0.20$ & 93.00 \\
$\mathrm{Mg}$ & 1.00 & $1.09 \pm 0.20$ & 109.00 \\
$\mathrm{Mn}$ & 1.00 & $1.03 \pm 0.10$ & 103.00 \\
$\mathrm{Mo}$ & 1.00 & $0.92 \pm 0.03$ & 92.00 \\
$\mathrm{Na}$ & 1.00 & $0.90 \pm 0.20$ & 90.00 \\
$\mathrm{Ni}$ & 1.00 & $0.90 \pm 0.04$ & 90.00 \\
$\mathrm{P}$ & 1.00 & $0.93 \pm 0.05$ & 93.00 \\
$\mathrm{~S}$ & 1.00 & $0.90 \pm 0.03$ & 90.00 \\
$\mathrm{Se}$ & 1.00 & $1.03 \pm 0.06$ & 103.00 \\
$\mathrm{~V}$ & 1.00 & $0.92 \pm 0.02$ & 92.00 \\
$\mathrm{Zn}$ & 1.00 & $1.08 \pm 0.05$ & 108.00 \\
\hline
\end{tabular}

The results are expressed as mean $\pm \mathrm{SD}$.

pos(50,50), size(200,200), bgcol(156)]]ted in flowers and bracts of the banana tree's inflorescence were $90.100 \pm 0.859 \mathrm{mg} / 100 \mathrm{~g}$ and $75.597 \pm 0.290 \mathrm{mg} / 100 \mathrm{~g}$ ( Table 6). Sulfur does not have an established RDA [28]. Although there is no known dietary requirement for Sulfur, some experts recommend $800-900 \mathrm{mg} /$ day of Sulfur for adults, $1,200 \mathrm{mg} /$ day for pregnant women, and $1,500 \mathrm{mg} /$ day for patients with osteoarthritis [41].

The safe limit for Sulfur has not been established by UL for males, females, children, and pregnant women (Table 6). The chemical element sulfur is not toxic; however, 
TABle 5: Mineral composition of the flowers and bracts in the banana inflorescence by ICP OES (mg/100 g).

\begin{tabular}{lccc}
\hline $\begin{array}{l}\text { Available } \\
\text { elements }\end{array}$ & $\begin{array}{c}\text { Flowers } \\
(\mathrm{mg} / 100 \mathrm{~g})\end{array}$ & $\begin{array}{c}\text { Bracts } \\
(\mathrm{mg} / 100 \mathrm{~g})\end{array}$ & $p$ value \\
\hline $\mathrm{S}$ & $90.100 \pm 0.859$ & $75.597 \pm 0.290$ & $0.0001^{*}$ \\
$\mathrm{P}$ & $307.389 \pm 3.601$ & $282.398 \pm 0.551$ & $0.001^{*}$ \\
$\mathrm{Mg}$ & $171.602 \pm 2.261$ & $172.686 \pm 2.028$ & 0.570 \\
$\mathrm{Ca}$ & $285.444 \pm 5.412$ & $380.632 \pm 4.066$ & $0.0001^{*}$ \\
$\mathrm{Cr}$ & $0.027 \pm 0.016$ & $0.047 \pm 0.009$ & 0.140 \\
$\mathrm{Ni}$ & $0.072 \pm 0.003$ & $0.070 \pm 0.004$ & 0.998 \\
$\mathrm{Cu}$ & $0.385 \pm 0.007$ & $0.318 \pm 0.008$ & $0.0001^{*}$ \\
$\mathrm{Zn}$ & $2.565 \pm 0.037$ & $1.807 \pm 0.014$ & $0.0001^{*}$ \\
$\mathrm{Fe}$ & $1.844 \pm 0.052$ & $1.655 \pm 0.044$ & 0.008 \\
\hline
\end{tabular}

Values are mean \pm SD. ${ }^{*}$ Values along column are significantly different $(p<0.05)$.

some sulfur derivates are, such as sulfur dioxide and hydrogen sulfide. In humans, sulfate intake exceeds approximately $3 \mathrm{~g} /$ day due to sulfate ingestion in food and water [42]. On the other hand, the sulfur content of food can be estimated using the amino acids as methionine and cysteine [43].

FAO/WHO limits for edible plants have not yet been established for S [37]. In fact, studies on the intake of sulfurcontaining foods are scarce. There are no recognized toxic effects of dietary sulfur. It is not possible to affirm that banana inflorescence does not represent a risk of adverse health effects of males, females, children, and pregnant women.

According to data in Table 6, the contents of phosphorous detected in the flowers were $307.389 \pm 3.601 \mathrm{mg} /$ $100 \mathrm{~g}$, which corresponds to $43.912 \pm 0.514 \%$ of the total intake of $700 \mathrm{mg} /$ day of RDA for male, female, and pregnant women and $61.477 \pm 0.72 \%$ for children. Besides, the concentration of P detected in bracts was $282.398 \pm 0.551 \mathrm{mg} /$ $100 \mathrm{~g}$, corresponding to $40.34 \pm 0.071 \%$ of the RDA for males, females, and pregnant women and $56.479 \pm 0.110 \%$ for children. Thus, flowers and bracts can be considered as excellent sources of P (more than 20\% of DRI) for adults, pregnant women, and children aged 4-8 years (Table 6).

The level of $\mathrm{P}$ determined in the flowers and bracts of the inflorescence does not represent a health risk because it is below the UL for P's consumption in men, women, children, adolescents, and pregnant women (3,000-4,000 mg/100 g) (Table 6). For edible plants, the FAO/WHO limits have not yet been established for $\mathrm{P}$ [36]. Foods rich in phosphorus are beneficial to human health. However, excess phosphorus can cause body changes and have critical negative effects on bone health [44].

In Table 6, the concentration of magnesium detected in flowers was $171.602 \pm 2.261 \mathrm{mg} / 100 \mathrm{~g}$, which corresponds to $40.71 \pm 0.53 \%$ of RDA for males ( $420 \mathrm{mg} /$ day), $53.43 \pm 0.70 \%$ of RDA for females (320 mg/day), $131.53 \pm 1.73 \%$ of RDA for children $(110 \mathrm{mg} /$ day), and $47.50 \pm 0.62 \%$ of RDA for pregnant women $(360 \mathrm{mg} /$ day). The concentration of $\mathrm{Mg}$ in bracts detected $(172.686 \pm 2.028 \mathrm{mg} / 100 \mathrm{~g})$ correspond to $40.95 \pm 0.48 \%$ of the RDA for male, $53.75 \pm 0.63 \%$ of RDA for females, $132.0 \pm 1.56 \%$ of the RDA for children, and
$47.77 \pm 0.56 \%$ of RDA for pregnant women. Therefore, the flowers and bracts are an excellent $\mathrm{Mg}$ source for people in this age group of 4 to 50 years.

The concentration of $\mathrm{Mg}$ was found to be the same in flowers and bracts, which is below the permissible level of $350 \mathrm{mg} /$ day set by UL [28]. Therefore, the inflorescence of the banana tree does not represent a risk of adverse health effects for males, females, children, adolescents, and pregnant women. There is no limit for $\mathrm{Mg}$ in edible plants established by FAO/WHO.

Studies have demonstrated the effect of $\mathrm{Mg}$ supplementation in the treatment of some diseases [45]. However, $\mathrm{Mg}$ toxicity occurs during intravenous $\mathrm{Mg}$ treatment [46]. To date, we have not found published papers on magnesium toxicity due to food intake. In clinical practice, the magnesium diet and supplementation appear to be reliable [47]. Studies on supplementing $360 \mathrm{mg} /$ day of $\mathrm{Mg}$ in pregnancy demonstrated efficacy concerning ameliorating muscle cramps [48].

The level of calcium in the flowers was $285.444 \pm 5.412 \mathrm{mg} / 100 \mathrm{~g}$ (Table 6), corresponding to $28.544 \pm 0.542 \%$ of the $1000 \mathrm{mg} /$ day recommended for men by AI for male, females, and pregnant women and $35.680 \pm 0.676 \%$ of the AI for children $(800 \mathrm{mg} /$ day $)$. Bracts $(380.632 \pm 4.066 \mathrm{mg} / 100 \mathrm{~g})$ correspond to $38.063 \pm 0.406 \%$ of the AI for males, females, and pregnant women and $47.579 \pm 0.508 \%$ for children. Consequently, it is concluded that the flowers and bracts are excellent $\mathrm{Ca}$ source for people in the age group of 31 to 50 years and children. In recent years, based on various clinical practice guidelines, calcium has been supplemented taken for men and women, children, and adults to improve their skeletal health [49].

The Ca level in Table 6 (flowers and bracts) was below the UL values for Ca's consumption in males and females $(2,500 \mathrm{mg} /$ day $)$, with no risk of adverse health effects. For edible plants, the FAO/WHO limits have not yet been established for $\mathrm{Ca}$ [37]. According to Bernett et al. [50], calcium intake's toxic effects have only been reported when the calcium is given the carbonate in very high doses.

According to data in Table 6, the chromium concentration found in flowers $(0.027 \pm 0,006 \mathrm{mg} / 100 \mathrm{~g})$ corresponds to $77.142 \pm 17.14 \%$ of the AI for male $(0.035 \mathrm{mg} /$ day $)$, $108.0 \pm 10.8 \%$ of the AI for females $(0.025 \mathrm{mg} /$ day $)$, $180.0 \pm 40 \%$ of AI for children $(0.015 \mathrm{mg} /$ day $)$, and $90 \pm 20 \%$ for pregnant women $(0.030 \mathrm{mg} /$ day $)$. The content found in bracts $\quad(0.047 \pm 0.009 \mathrm{mg} / 100 \mathrm{~g}) \quad$ corresponds to $134.285 \pm 25.714 \%$ of the AI for male, $188.0 \pm 36.0 \%$ of the AI for females, $313.33 \pm 60 \%$ for children, and $156.66 \pm 30 \%$ for pregnant women. After comparison of the concentration of $\mathrm{Cr}$ in flowers and bracts with those values proposed by the $\mathrm{AI}$, it is concluded that the flowers and bracts are an excellent source of $\mathrm{Cr}$ for people in the age group of 31 to 50 years and children aged $4-8$ years.

There are no established limits by UL for Cr for these populations (Table 6). However, it was found that the concentration of $\mathrm{Cr}$ in flowers and bracts was higher than the allowed limit established by FAO in edible plants $(0.002 \mathrm{mg} / 100 \mathrm{~g})$ [37]. The National Academy of Sciences has determined a safe and adequate daily intake for Cr (III) 
TABLE 6: Nonmetals and heavy metals quantified in banana inflorescences (flowers and bracts) compared to nutritional recommendations for adults, children, and pregnancy.

\begin{tabular}{|c|c|c|c|c|c|c|c|c|c|c|}
\hline & \multirow{2}{*}{$\begin{array}{l}\text { Flowers } \\
(\mathrm{mg} / 100 \mathrm{~g})\end{array}$} & \multirow{2}{*}{$\begin{array}{c}\text { Bracts } \\
(\mathrm{mg} / 100 \mathrm{~g})\end{array}$} & \multirow{2}{*}{$\begin{array}{c}\text { Males } \\
31-50 \mathrm{y} \\
1 \mathrm{RDA} / \mathrm{AI}^{*} \\
(\mathrm{mg} / \text { day })\end{array}$} & \multirow{2}{*}{$\begin{array}{c}\text { females } \\
31-50 \mathrm{y} \\
1 \mathrm{RDA} / \mathrm{AI}^{*} \\
(\mathrm{mg} / \text { day) }\end{array}$} & \multirow{2}{*}{$\begin{array}{c}\text { Males/ } \\
\text { females } \\
31-50 y \\
\text { UL } \\
\text { (mg/day }\end{array}$} & \multicolumn{2}{|c|}{$\begin{array}{c}\text { Children } \\
4-8 \mathrm{y}\end{array}$} & \multicolumn{2}{|c|}{$\begin{array}{c}\text { Pregnancy } \\
31-50 \mathrm{y}\end{array}$} & \multirow{2}{*}{$\begin{array}{c}\text { Edible plant } \\
2 \mathrm{FAO} / \mathrm{WHO} \\
(\mathrm{mg} / 100 \mathrm{~g})\end{array}$} \\
\hline & & & & & & $\begin{array}{c}\text { 1RDA/AI* } \\
\text { (mg/day) }\end{array}$ & $\begin{array}{c}\mathrm{UL} \\
\text { (mg/day) }\end{array}$ & $\begin{array}{c}1 \mathrm{RDA} / \mathrm{AI}^{*} \\
\text { (mg/day) }\end{array}$ & $\begin{array}{c}\mathrm{UL} \\
\text { (mg/day) }\end{array}$ & \\
\hline \multicolumn{11}{|c|}{ Nonmetals } \\
\hline S & $90.100 \pm 0.859$ & $75.597 \pm 0.290$ & ND & ND & ND & ND & ND & ND & ND & ND \\
\hline $\mathrm{P}$ & $307.389 \pm 3.601$ & $282.398 \pm 0.551$ & 700 & 700 & 4,000 & 500 & 3,000 & 700 & 3,500 & ND \\
\hline \multicolumn{11}{|c|}{ Metals } \\
\hline $\mathrm{Mg}$ & $171.602 \pm 2.261$ & $172.686 \pm 2.028$ & 420 & 320 & 350 & 130 & $110^{* *}$ & 360 & $350^{* *}$ & ND \\
\hline $\mathrm{Ca}$ & $285.444 \pm 5.412$ & $380.632 \pm 4.066$ & $1,000^{*}$ & $1,000^{*}$ & 2,500 & $800^{*}$ & 2,500 & $1,000^{*}$ & 2,500 & ND \\
\hline $\mathrm{Cr}$ & $0.027 \pm 0.006$ & $0.047 \pm 0.009$ & $0.035^{*}$ & $0.025^{*}$ & ND & $0.015^{*}$ & ND & $0.030^{*}$ & ND & 0.002 \\
\hline $\mathrm{Ni}$ & $0.072 \pm 0.003$ & $0.070 \pm 0.004$ & ND & ND & 1 & ND & 0.3 & ND & 1 & 0.163 \\
\hline $\mathrm{Cu}$ & $0.385 \pm 0.007$ & $0.318 \pm 0.008$ & 0.9 & 0.9 & 10 & 0.440 & 3 & 1 & 10 & 0.3 \\
\hline $\mathrm{Zn}$ & $2.565 \pm 0.037$ & $1.807 \pm 0.014$ & 11 & 8 & 40 & 5 & 12 & 11 & 40 & 2.74 \\
\hline $\mathrm{Fe}$ & $1.84 \pm 0.520$ & $1.66 \pm 0.440$ & 8 & 18 & 45 & 10 & 40 & 27 & 45 & 2.0 \\
\hline
\end{tabular}

Note. $\mathrm{ND}=$ not determined; ${ }^{1}$ Recommended Dietary Allowances (RDA) [28]. ${ }^{*}$ The value for AI is used when there are no calculated values for the RDA. ${ }^{2} \mathrm{FAO} / \mathrm{WHO}(1984)(\mathrm{mg} / 100 \mathrm{~g})$ [37]. ${ }^{* *}$ The ULs for magnesium represents intake from a pharmacological agent only and do not include intake from food and water.

in adults of 50-200 micrograms per day, respectively [51]. Therefore, special care should be taken with respect to the ingestion of this vegetable in large quantities.

The nickel concentration obtained in the flowers and bracts of the Banana tree's inflorescence was $0.072 \pm 0.003 \mathrm{mg} / 100 \mathrm{~g}$ and $0.070 \pm 0.004 \mathrm{mg} / 100 \mathrm{~g}$ (Table 6). There is no limit for Ni concentration established by RDA and $\mathrm{AI}$ values for people. However, the concentration of $\mathrm{Ni}$ in flowers and bracts are below UL values for adults aged $31-50$ years $(1.0 \mathrm{mg} /$ day $)$ and children aged $4-8$ years $(0.3 \mathrm{mg} /$ day $)$.

The permissible limit set by $\mathrm{FAO} / \mathrm{WHO}$ for edible plants was $0.163 \mathrm{mg} / 100 \mathrm{~g}$ (Table 6) [36]. According to the DEPARTMENT of HEALTH AND HUMAN SERVICES, Public Health Service Agency for Toxic Substances and Disease Registry, food is the major source of nickel exposure for adults and children (dietary intake, $0.170 \mathrm{mg} /$ day) [52]. Studies on Nickel's dietary intake assessment indicate that the diet provides less than $0.2 \mathrm{mg} /$ day [53]. Thus, it is found that the inflorescence of the banana tree does not represent a risk of adverse health, since the accumulated $\mathrm{Ni}$ in flowers and bracts are below the limits set $[28,52,53]$.

The content detected of copper in flowers $(0.385 \pm 0.007 \mathrm{mg} / 100 \mathrm{~g})$ correspond to $42.77 \pm 0.77 \%$ of the RDA for male and females $(0.9 \mathrm{mg} /$ day $), 87.50 \pm 1.59 \%$ for children $(0.440 \mathrm{mg} /$ day $)$, and $38.50 \pm 0.70 \%$ for pregnant women $(1 \mathrm{mg} /$ day). On the other hand, the content detected of $\mathrm{Cu}$ in bracts was $0.318 \pm 0.008 \mathrm{mg} / 100 \mathrm{~g}$, which correspond to $35.33 \pm 8.88 \%$ of the RDA for male and females, $72.272 \pm 1.81 \%$ for children, and $31.80 \pm 0.80 \%$ for pregnant women. According to these results, flowers and bracts are an excellent source of $\mathrm{Cu}$ for people in the age group of 31 to 50 years and children aged $4-8$ years.

Cu's concentration in the banana inflorescence is lower than the values established by UL for adults, children, and pregnant women $(3-10 \mathrm{mg} /$ day). However, it is higher than the concentration of edible plants established by FAO/WHO $(0.3 \mathrm{mg} / 100 \mathrm{~g})$ [37]. High concentration copper in foods can cause adverse long-term effects in humans [54]. Exposure to excessive copper levels can result in kidney damage, anemia, immunotoxicity, and developmental toxicity [55].

The content of Zinc in flowers was $2.565 \pm 0.037 \mathrm{mg} / 100 \mathrm{~g}$ (Table 6), whose percentage was $24.14 \pm 0.336 \%$ of value established by $\mathrm{RDA}$ for male and pregnant women ( $11 \mathrm{mg} /$ day), $32.06 \pm 0.46 \%$ for females $(8 \mathrm{mg} /$ day $)$, and $51.30 \pm 0.74 \%$ for children $(5 \mathrm{mg} /$ day $)$. $\mathrm{Zn}$ concentration in bracts $\quad(1.807 \pm 0.014 \mathrm{mg} /$ day $)$ corresponded to $16.427 \pm 0.127 \%$ of value established by RDA for male and pregnant women, $22.587 \pm 0175 \%$ for females, and $36.14 \pm 0.28 \%$ for children. Flowers are an excellent source of $\mathrm{Zn}$ to males, females, children, and pregnant women. The bracts are a good source of $\mathrm{Zn}$ for males and pregnant women; they are excellent $\mathrm{Zn}$ sources to females and children.

The $\mathrm{Zn}$ level in Table 6 is below the UL for the consumption of $\mathrm{Zn}$ in males, females, and pregnant women ( $40 \mathrm{mg} /$ day) and children ( $12 \mathrm{mg} /$ day). The permissible limit set by $\mathrm{FAO} / \mathrm{WHO}$ for $\mathrm{Cu}$ in edible plants was $2.74 \mathrm{mg} / 100 \mathrm{~g}$ [37]. Thus, the plant accumulated Zn below this limit.

Dietary zinc levels are recommended during pregnancy and lactation [56]. Besides, supplementation with zinc showed efficacy in the treatment of some diseases [57].

In Table 6 the concentration of iron in flowers $(1.84 \pm 0.520 \mathrm{mg} / 100 \mathrm{~g})$ correspond to $23.05 \pm 6.50 \%$ of the $\mathrm{RDA}$ for male ( $8 \mathrm{mg}$ /day), $10.24 \pm 0.28 \%$ of RDA for females ( $18 \mathrm{mg} /$ day), $18.40 \pm 5.2 \%$ for children $(10 \mathrm{mg} /$ day $)$, and $6.81 \pm 1.92 \%$ for pregnant women $(27 \mathrm{mg} /$ day $)$. The concentration of $\mathrm{Fe}$ for bracts $(1.66 \pm 0.440 \mathrm{mg} / 100 \mathrm{~g})$ corresponds to $20.68 \pm 5.5 \%$ of the RDA for male, $9.22 \pm 2.44 \%$ of RDA for females, $16.60 \pm 4.4 \%$ of the RDA for children, and $6.14 \pm 1.62 \%$ of RDA for pregnant women. After comparison of the concentration of Fe in flowers and bracts with those values proposed by the RDA [28], it was found that the flowers and bracts are an excellent source of Fe for males. On the other hand, flowers are a good source of Fe for females and children. Bracts are a good source of Fe for children, respectively. 
Fe concentration in flowers and bracts is below the permissible level of $45 \mathrm{mg} /$ day set by UL [28]. Therefore, the banana tree's inflorescence does not represent a risk of adverse health effects for males, females, children, and pregnant women. In fact, the ingestion of less than $20 \mathrm{mg} / \mathrm{kg}$ of elemental iron is nontoxic; however, ingestion of more than $60 \mathrm{mg} / \mathrm{kg}$ can result in severe toxicity and lead to severe morbidity and mortality [58]. Fe's concentration in the banana bracts and flowers is close to the value allowed by FAO/WHO for edible plants, which is $2.0 \mathrm{mg} / 100 \mathrm{~g}$ [37].

In the paper published by Oyeyinka and Afolayan [33], elements as $\mathrm{Ca}, \mathrm{Mn}, \mathrm{P}, \mathrm{Na}, \mathrm{Zn}, \mathrm{Mg}, \mathrm{Cu}, \mathrm{Fe}$, and $\mathrm{K}$ were quantified in the peel, flesh, and peel extract of $M$. sinensis and $M$. paradisiaca. On the other hand, in our paper, the inflorescence and flowers of the $M$. paradisiaca were quantified $\mathrm{P}, \mathrm{S}, \mathrm{Ca}, \mathrm{Mg}, \mathrm{Zn}, \mathrm{Fe}, \mathrm{Cu}, \mathrm{Ni}$, and $\mathrm{Cr}$. Thus, inflorescence and banana flowers can be considered as food for people.

\section{Conclusions}

New information on the concentration of macro- and microelements in the inflorescence of Musa paradisiaca was obtained and compared with recommended values (RDA/AI), tolerable upper intake levels (ULs), and edible plants. Flowers and bracts are an excellent source of $\mathrm{Mg}, \mathrm{Ca}, \mathrm{P}, \mathrm{Cr}, \mathrm{Cu}$, and $\mathrm{Zn}$ for males and females.

For elements such as sulfur and nickel, the present study showed that there are gaps regarding knowledge of the levels in which nutrients can be ingested (RDA/AI), especially children and pregnant women.

There are no limits established to $\mathrm{S}, \mathrm{Mg}, \mathrm{Ca}$, and $\mathrm{P}$ by FAO/WHO for edible plants. However, the concentrations of $S$ were low relative to values stipulated by experts.

UL has not yet established the limits for chromium, sulfur, and nickel. However, the present study showed that $M$. paradisiaca's inflorescence accumulates chromium and copper above the limit set by FAO/WHO (edible plant). On the other hand, the concentration of $\mathrm{Mg}, \mathrm{Ca}, \mathrm{P}, \mathrm{Ni}, \mathrm{Cu}, \mathrm{Zn}$, and Fe was low relative to the UL's values. The concentration of $\mathrm{Ni}$ and $\mathrm{Zn}$ is below the amount established by FAO/WHO in edible plants.

The data obtained would serve as a tool for deciding the dosage of this vegetable with nutritional purposes. However, in some cases, they carry very high content of toxic metals whose main reason is environmental factors. Therefore, special care should be taken regarding the daily intake of this unconventional food. Prolonged ingestion of metals such as chromium, copper, nickel, and zinc can cause deleterious health effects in humans.

The knowledge of the nonconventional plants has an economic interest and involves a global health problem. This paper's results and discussion would represent further valid contributions to the scientific research, farmers, and other stakeholders as governmental and nongovernmental organizations (NGOs) and society at large. Research on the inflorescence of other banana species can be conducted by opening doors for new food products.

\section{Data Availability}

The data used to support the findings of this study are included and referred within the article.

\section{Conflicts of Interest}

The authors declare that there are no conflicts of interest regarding the publication of this paper.

\section{Acknowledgments}

This research was supported by the National Council for Scientific and Technological Development, Brazil, (CNPq: Process No. 311336/2017-5). This study was financed in part by the Coordenação de Aperfeiçoamento de Pessoal de Nível Superior, Brazil (CAPES), Finance Code 001.

\section{References}

[1] H. T. Vu, C. J. Scarlett, and Q. V. Vuong, "Phenolic compounds within banana peel and their potential uses: a review," Journal of Functional Foods, vol. 40, pp. 238-248, 2018.

[2] R. C. Ploetz, A. K. Kepler, J. Daniells, and S. C. Nelson, "Banana and plantain-an overview with emphasis on the pacific island cultivars," Species Profiles for Pacific Island Agroforestry, vol. 1, pp. 21-32, 2007.

[3] R. Valmayor, S. Jamaluddin, B. Silayoi et al., Banana Cultivar Names and Synonyms in Southeast Asia, Vol. 55, International Network for Improvement of Banana and Plantain-Asia and the Pacific Office, Los Baños, Philippines, 2000.

[4] K. P. S. Kumar, D. Bhowmik, S. Duraivel, and M. Umadevi, "Traditional and medicinal uses of banana," Journal of Pharmacognosy and Phytochemistry, vol. 1, pp. 51-63, 2012.

[5] J. Kennedy, "Bananas and people in the homeland of genus musa: not just pretty fruit," Ethnobotany Research and Applications, vol. 7, pp. 179-197, 2009.

[6] A. L. Falcomer, R. F. R. Riquette, B. R. de Lima, V. C. Ginani, and R. P. Zandonadi, "Health benefits of green banana consumption: A systematic eview," Nutrients, vol. 11, no. 6, p. 1222, 2019.

[7] B. G. Oliveira, E. F. Pimentel, A. C. H. Pereira et al., "Phenolic and glycidic profiling of bananas musa sp associated with maturation stage and cancer chemoprevention activities," Microchemical Journal, vol. 153, Article ID 104391, 2020.

[8] A. Mohiuddin, M. K. Saha, M. S. Hossian, and A. Ferdoushi, "Usefulness of banana (musa paradisiaca) wastes in manufacturing of bio-products: a review," The Agriculturists, vol. 12, no. 1, pp. 148-158, 2014.

[9] Food and Agriculture Organization (FAO), "Banana facts and figures," 2019, http://www.fao.org/economic/est/estcommodities/bananas/bananafacts/en/\#.XT34WuhKjIV.

[10] C. E. Fingolo, J. M. A. Braga, A. C. M. Vieira, M. R. L. Moura, and M. A. C. Kaplan, "The natural impact of banana inflorescences (musa acuminata) on human nutrition," Anais da Academia Brasileira de Ciências, vol. 84, no. 4, pp. 891-898, 2012.

[11] F. Khanum, M. Siddalinga Swamy, K. R. Sudarshana Krishna, K. Santhanam, and K. R. Viswanathan, "Dietary fiber content of commonly fresh and cooked vegetables consumed in India," Plant Foods for Human Nutrition, vol. 55, no. 3, pp. 207-218, 2000. 
[12] D. Lin, Y. Ouyang, C. H. Huang, and D. Y. Huang, "Characterization of heavy metals from banana farming soils," CLEAN-Soil, Air, Water, vol. 38, no. 5-6, pp. 430-436, 2010.

[13] N. K. Sahodaran and J. G. Ray, "Heavy metal contamination in "chemicalized" green revolution banana fields in southern India," Environmental Science and Pollution Research, vol. 25, no. 27, pp. 26874-26886, 2018.

[14] A. B. J. Mohamed, M. H. Ali, S. A. Khamis, and A. I. Ali, "Level of nutritious and non- nutritious elements in banana grown in zanzibar," Academic Journal of Chemistry, vol. 2, pp. 21-27, 2017.

[15] V. Flores, C. Victorio, I. Direito, and A. Cardoso, "Heavy metals accumulation in banana (musa spp.) leaves from industrial area in rio de Janeiro," Orbital: The Electronic Journal of Chemistry, vol. 10, no. 4, 2018.

[16] D. Romero-Estévez, G. S. Yánez-Jácome, K. Simbaña-Farinango, and H. Navarrete, "Distribution, contents, and health risk assessment of cadmium, lead, and nickel in bananas produced in Ecuador," Foods, vol. 8, no. 8, p. 330, 2019.

[17] A. R. Ghazali, N. E. A. Razak, M. S. Othman et al., "Study of heavy metal levels among farmers of muda agricultural development authority, Malaysia," Journal of Environmental and Public Health, vol. 2012, Article ID 758349, 4 pages, 2012.

[18] R. J. Marles, "Mineral nutrient composition of vegetables, fruits and grains: the context of reports of apparent historical declines," Journal of Food Composition and Analysis, vol. 56, pp. 93-103, 2017.

[19] U. Y. Stambulska, M. M. Bayliak, and V. I. Lushchak, "Chromium(VI) toxicity in legume plants: MODULATION effects of rhizobial symbiosis," BioMed Research International, vol. 2018, Article ID 8031213, 13 pages, 2018.

[20] F. A. Bashir, M. Shuhaimi-Othman, and A. G. Mazlan, "Evaluation of trace metal levels in tissues of two commercial fish species in kapar and mersing coastal waters, peninsular Malaysia," Journal of Environmental and Public Health, vol. 2012, Article ID 352309, 10 pages, 2012.

[21] R. Dghaim, S. A. Khatib, H. Rasool, and M. A. Khan, "Determination of heavy metals concentration in traditional herbs commonly consumed in the United Arab Emirates," Journal of Environmental and Public Health, vol. 2015, Article ID 973878, 6 pages, 2015.

[22] O. Miedico, C. Pompa, C. Tancredi et al., "Characterisation and chemometric evaluation of 21 trace elements in three edible seaweed species imported from south-east Asia," Journal of Food Composition and Analysis, vol. 64, pp. 188197, 2017.

[23] A. A. Bawuro, R. B. Voegborlo, and A. A. Adimado, "Bioaccumulation of heavy metals in some tissues of fish in lake geriyo, adamawa state, Nigeria," Journal of Environmental and Public Health, vol. 2018, Article ID 1854892, 7 pages, 2018.

[24] K. I. Kasozi, P. C. Natabo, S. Namubiru, D. S. Tayebwa, A. Tamale, and P. H. Bamaiyi, "Food safety analysis of milk and beef in southwestern Uganda," Journal of Environmental and Public Health, vol. 2018, Article ID 1627180, 7 pages, 2018.

[25] Food and Agriculture Organization (FAO), "Good agricultural practices for bananas," 2019, http://www.fao.org/world-bananaforum/projects/good-practices/good-agricultural-practices/en/.

[26] P. T. Bhattacharya, S. R. Misra, and M. Hussain, "Nutritional aspects of essential trace elements in oral health and disease: an extensive review," Scientifica, vol. 2016, Article ID 5464373, 12 pages, 2016.
[27] I. Evans and E. Solberg, Minerals for Plants, Animals and Man. Agri-Facts (Agdex 531-3), Alberta agriculture Food and Rural Development, Alberta, Canada, 1998.

[28] Institute of Medicine, Dietary Reference Intakes: The Essential Guide to Nutrient Requirements, The National Academies Press, Washington, DC, USA, 2006.

[29] K. Artwell, N. France, and K. Florence, "Investigation of some metals in leaves and leaf extracts of lippiajavanica: its daily intake," Journal of Environmental and Public Health, vol. 2017, Article ID 1476328, 9 pages, 2017.

[30] N. Bilandžić, M. Sedak, M. Đokić et al., "Determination of zinc concentrations in foods of animal origin, fish and shellfish from Croatia and assessment of their contribution to dietary intake," Journal of Food Composition and Analysis, vol. 35, pp. 61-66, 2014.

[31] J. R. Bogard, S. H. Thilsted, G. C. Marks et al., "Nutrient composition of important fish species in Bangladesh and potential contribution to recommended nutrient intakes," Journal of Food Composition and Analysis, vol. 42, pp. 120133, 2015.

[32] G. Luis, C. Rubio, C. Revert et al., "Dietary intake of metals from yogurts analyzed by inductively coupled plasma optical emission spectrometry (ICP-OES)," Journal of Food Composition and Analysis, vol. 39, pp. 48-54, 2015.

[33] B. O. Oyeyinka and A. J. Afolayan, "Comparative evaluation of the nutritive, mineral, and antinutritive composition of Musa sinensis L. (Banana) and Musa paradisiaca L. (Plantain) fruit compartments," Plants, vol. 8, no. 12, p. 598, 2019.

[34] L. S. Rocha, D. G. Arakaki, D. Bogo et al., "Evaluation of level of essential elements and toxic metal in the medicinal plant hymenaea martiana hayne (jatobá) used by mid-west population of Brazil," The Scientific World Journal, vol. 2019, Article ID 4806068, 7 pages, 2019.

[35] R. Beghi, V. Giovenzana, A. Tugnolo, and R. Guidetti, "Application of visible/near infrared spectroscopy to quality control of fresh fruits and vegetables in large-scale mass distribution channels: a preliminary test on carrots and tomatoes," Journal of the Science of Food and Agriculture, vol. 98, no. 7, pp. 2729-2734, 2018.

[36] A. Apolonski, S. Roy, R. Lampe, and K. Maiti, "Molecular identification of bio-fluids in gas phase using infrared spectroscopy," Applied Optics, vol. 59, no. 17, pp. E36-E41, 2020.

[37] Food and Agriculture Organization/Word Health Organization (FAO/WHO), FAO/WHO, Food Contaminants. in. Codex Alimentarius Commmission, Vol. XVII, Food and Agriculture Organization/Word Health Organization (FAO/ WHO), Rome, Italy, 1984.

[38] G. L. Sankar Maiti and J. D. Winefordner, "Limit of detection. A closer look at the IUPAC definition," Analytical Chemistry, vol. 55, no. 7, pp. 712A-724A, 1983.

[39] E. Brima, "Toxic elements in different medicinal plants and the impact on human health," International Journal of Environmental Research and Public Health, vol. 14, no. 10, p. 1209, 2017.

[40] US Department of Agriculture; US Department of Health and Human Services, "Food labeling, CFR-Code of federal regulations title 21," 2018, https://www.accessdata.fda.gov/ scripts/cdrh/cfdocs/cfcfr/CFRSearch.cfm? CFRPart $=101 \&$ showFR $=1$.

[41] T. M. Michael, E. P. Joseph, and P. Lara, The Encyclopedia of Healing Foods, Editora: Simon \& Schuster, New York, NY, USA, 2005.

[42] Dietary Reference Intakes for Water, Potassium, Sodium, Chloride, and Sulfate, Standing Committee on the Scientific 
Evaluation of Dietary Reference Intakes. Food and Nutrition Board, Institute Of Medicine of the National Academies. The National Academies Press, Washington, DC, USA, 2005.

[43] US Food and Drug Administration, "Food additive status list," 2018, https://www.fda.gov/food/ingredientspackaginglabeling/ foodadditivesingredients/ucm091048.htm.

[44] C. J. Vorland, E. R. Stremke, R. N. Moorthi, and K. M. Hill Gallant, "Effects of excessive dietary phosphorus intake on bone health," Current Osteoporosis Reports, vol. 15, no. 5, pp. 473-482, 2017.

[45] N. E. L. Saris, E. Mervaala, H. Karppanen, J. A. Khawaja, and A. Lewenstam, "Magnesium," Clinica Chimica Acta, vol. 294, no. $1-2$, pp. 1-26, 2000

[46] J. P. Knochel, A. S. Fauci, E. Braunwald, K. J. Isselbacher, and J. B. Martin, Disorders of Magnesium Metabolism. Harrison's Principles of Internal Medicine, McGraw-Hill, New York, NY, USA, 14th edition, 1997.

[47] G. K. Schwalfenberg and S. J. Genuis, "The importance of magnesium in clinical healthcare," Scientifica, vol. 2017, Article ID 4179326, 14 pages, 2017.

[48] G. Young and D. Jewell, "Interventions for leg cramps in pregnancy," Cochrane Database of Systematic Reviews, vol. 1, 2002.

[49] K. Li, X. F. Wang, D. Y. Li et al., "The good, the bad, and the ugly of calcium supplementation: a review of calcium intake on human health," Clinical Interventions in Aging, vol. 13, pp. 2443-2452, 2018.

[50] C. H. Bernett, R. R. Commons, F. Albright, and J. E. Howard, "Hypercalcaemia without hypercalciuria or hypophosphatemia, calcinosis and renal insufficiency. A syndrome following prolonged intake of milk and alkali," The New England Journal of Medicine, vol. 240, pp. 787-794, 1949.

[51] ATSDR, "Chromium (Cr) toxicity: key concepts | ATSDR-environmental health and medicine education. ATSDR,” 2008, https://www.atsdr.cdc.gov/csem/csem.asp? csem $=10 \& p o=0 \% 20$.

[52] US Department of Health and Human Services, Public Health Service, Agency for Toxic Substances and Disease Registry (ATSDR), Public Health Statement: Ammonia, England, UK, 2004.

[53] World Health Organization, Nickel in Drinking-Water Background Document for Development of WHO Guidelines for Drinking-Water Quality, WHO information products on water, sanitation, hygiene and health, Geneva, Switzerland, 2005.

[54] B. Muriel, H. Sabine, O. Marion, K. Esther, H. Jean-François, and M. Irène, "Dietary copper and human health: current evidence and unresolved issues," Journal of Trace Elements in Medicine and Biology, vol. 35, pp. 107-115, 2016.

[55] P. B. Tchounwou, C. Newsome, J. Williams, and K. Glass, "Copper-induced cytotoxicity and transcriptional activation of stress genes in human liver carcinoma (HepG(2)) cells," in Proceedings of the International Symposium on Metal Ions in Biology and Medicine, vol. 10, pp. 285-290, 2008.

[56] F. Ejezie and U. Nwagha, "Zinc concentration during pregnancy and lactation in enugu, south-east Nigeria," The Annals of Medical and Health Science Research, vol. 1, no. 1, pp. 69-76, 2011.

[57] O. Fontaine, "Effect of zinc supplementation on clinical course of acute diarrhoea," Journal of Health, Population and Nutrition, vol. 19, no. 4, pp. 339-346, 2001.

[58] T. Madiwale and E. Liebelt, "Iron: not a benign therapeutic drug," Current Opinion in Pediatrics, vol. 18, no. 2, pp. 174-179, 2006. 